\title{
Correction to: Relationship between CT characteristics and human epidermal growth factor receptor 2 expression in gastric cancers
}

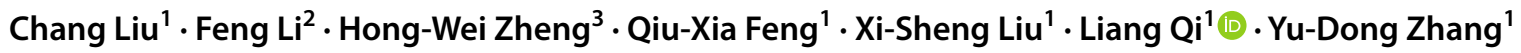

Published online: 17 September 2020

(c) Springer Nature Singapore Pte Ltd. 2020

\section{Correction to:}

Chinese Journal of Academic Radiology (2020)

https://doi.org/10.1007/s42058-020-00041-3

The original version of this article, published on June 17, 2020 , contained a mistake.

Although our article reports novel data and includes data on patients with resectable and non-resectable gastric cancer, we would like to acknowledge similarities in study design with the work of Lee et al. [1].

\section{References}

1. Lee JS, Kim SH, Im SA, Kim MA, Han JK. Human epidermal growth factor receptor 2 expression in unresectable gastric cancers: relationship with CT Characteristics. Korean J Radiol. 2017;18(5):809-20. https://doi.org/10.3348/kjr.2017.18.5.809.

Publisher's Note Springer Nature remains neutral with regard to jurisdictional claims in published maps and institutional affiliations.

The original article can be found online at https://doi.org/10.1007/ s42058-020-00041-3.

Liang Qi

qiliang1120@126.com

$\triangle$ Yu-Dong Zhang

pku_zyd06@163.com

1 Department of Radiology, The First Affiliated Hospital of Nanjing Medical University, Guangzhou Road 300, Nanjing 210029, People's Republic of China

2 Department of Radiology, Xiangyang Central Hospital, Affiliated Hospital of Hubei University of Arts and Science, Jingzhou Road 39, Xiangyang, Hubei 441021, People's Republic of China

3 Imaging Department, Henan Provincial Hospital, Huaxiadadao, Zhengzhou, Henan 100142,

People's Republic of China 